\title{
NAPROXEN SODIUM DECREASES MIGRAINE RECURRENCE WHEN ADMINISTERED WITH SUMATRIPTAN
}

\author{
ABOUCH VALENTY KRYMCHANTOWSKI*
}

\begin{abstract}
Forty to $78 \%$ of the patients using sumatriptan for the acute treatment of migraine may present recurrence at least occasionally. The concomitant use of a NSAID (nonsteroidal anti-inflammatory drug) has been recommended to decrease the recurrence rate. Sixty seven patients that treated successfully 8 migraine attacks with $100 \mathrm{mg}$ of sumatritpan $\mathrm{PO}$ and presented recurrence in at least 5 attacks were studied prospectively. The patients received $100 \mathrm{mg}$ of sumatriptan and $550 \mathrm{mg}$ of naproxen sodium PO to treat 4 consecutive moderate or severe migraine attacks. The recurrence rate, once at least $62.5 \%$ (5 out of 8 attacks), decreased to $14.2 \%$ (38 out of 268 attacks) with the combination of compounds ( $\mathrm{p}<0.0001)$. We then studied two groups of 13 patients made randomicaly from the 67 initially evaluated, that were given sumatriptan $100 \mathrm{mg}$ plus naproxen sodium $550 \mathrm{mg}$ or placebo, in a double-blind design, to treat 3 other consecutive migraine attacks. Each group of patients treated 39 attacks. The recurrence among the patients taking sumatriptan plus placebo was $59 \%$ ( 23 out of 39 attacks) and the recurrence presented by the group taking sumatriptan plus naproxen was $25.5 \%$ (10 out of 39 attacks) $(\mathrm{p}<0.0003)$. We concluded that the combination of sumatriptan plus naproxen sodium decreases significantly migraine recurrence presented by patients taking sumatriptan alone.
\end{abstract}

KEY WORDS: migraine, recurrence, sumatriptan, naproxen sodium.

\section{Naproxeno sódico diminui a recorrência da migrânea quando administrado com o sumatriptan}

RESUMO - Quarenta a 78\% dos pacientes que utilizam sumatriptan para o tratamento agudo das migrâneas ou enxaquecas apresentam recorrência pelo menos ocasionalmente. O uso concomitante de um anti-inflamatório não esteroidal (AINE) tem sido recomendado para reduzir a frequência da recorrência. Sessenta e sete pacientes que haviam tratado com sucesso pelo menos 8 ataques de migrânea com $100 \mathrm{mg}$ de sumatriptan $\mathrm{VO}$, e apresentaram recorrência em pelo menos 5 ataques foram estudados prospectivamente. Os pacientes receberam $100 \mathrm{mg}$ de sumatriptan e $550 \mathrm{mg}$ de naproxen sodium VO para tratar 4 ataques consecutivos de intensidade moderada ou severa. A frequência da recorrência, que manifestava-se em pelo menos $62,5 \%$ ( 5 em cada 8 ataques), diminuiu para 14,2\% (38 em 268 ataques) com a combinação destes compostos (p<0,0001). Estudamos então 2 grupos de 13 pacientes formados randomicamente entre os 67 iniciais, aos quais foi dado sumatriptan $100 \mathrm{mg}$, e naproxen sodium $550 \mathrm{mg}$ ou placebo, de forma duplo-cega, para tratar 3 ataques consecutivos. Cada um dos 2 grupos tratou 39 ataques moderados ou intensos. A recorrência entre os pacientes do grupo que utilizou o sumatriptan mais placebo foi $59 \%$ ( $23 \mathrm{em} 39$ ataques) e a recorrência apresentada pelo grupo que utilizou sumatriptan e naproxen sodium foi $25,5 \%$ ( $10 \mathrm{em} 39$ ataques) ( $<<0,0003$ ). Concluímos que a combinação de sumatriptan e naproxen sodium diminui significativamente a recorrência dos ataques de migrânea em pacientes que fazem uso de sumatriptan isolado.

PALAVRAS-CHAVE: migrânea, recorrência, sumatriptan, naproxen sodium.

Sumatriptan is a serotonergic agonist of the receptors 5-HT 1B/1D effective in the acute treatment of migraine attacks ${ }^{1-6}$. Therefore, the recurrence of the headache may occur in 25 to $78 \%$ of the patients at least occasionally, and may represent a limitation to its use along with the possible

*Headache Center of Rio de Janeiro. (www.dordecabeca.com.br) and Institute of Neurology Deolindo outo. Aceite: 10-fevereiro-2000.

Dr. Abouch Valenty Krymchantowski - Rua Siqueira Campos 43/1002 - 22031-070 Rio de Janeiro RJ - Brasil. FAX 5521491 3657. E-mail: abouchkrym@openlink.com.br 
lack of efficacy, cost and/or side effects. The headache recurrence is particularly pointed as a major limitation for the use of sumatriptan ${ }^{2,7,8}$. Naproxen sodium is a nonsteroidal anti-inflammatory drug (NSAID) derivative of the propionic acid, also effective for the acute treatment of migraine ${ }^{9,10}$. The combination of the NSAID tolfenamic acid and the sumatriptan has been demonstrated to reduce the recurrence rate presented by the single use of sumatriptan in the acute treatment of migraine ${ }^{11}$. The objective of this study was then to evaluate whether the patients frequently presenting recurrence with sumatriptan, would decrease it with the combination of another NSAID, the naproxen sodium.

\section{METHOD}

Sixty seven patients, 56 women and 11 men, ages from 16 to 62 years were studied prospectively. Fifty four patients had the diagnosis of migraine without aura, 9 patients migraine without aura and migraine with aura and 4 migraine with aura according to the IHS criteria $^{12}$. All of the patients have treated at least 10 migraine attacks with $100 \mathrm{mg}$ of sumatriptan, that was effective in reducing the headache from moderate or severe, to mild or none in 2 hours, in at least 8 attacks. In at least 5 attacks successfully treated, there was recurrence in less than 24 hours. Recurrence was considered the returning of the headache after 2 hours and before 24 hours of the use of the sumatriptan. The study was conducted in two steps. Firstly, the patients were oriented to use the sumatriptan $100 \mathrm{mg}$ plus naproxen sodium $550 \mathrm{mg}$ PO during the first 60 minutes of an attack, as soon as the headache became moderate or intense, or upon wakening with it, since it was moderate or intense, during 4 attacks in the following 4 weeks. All of the patients recorded in a diary the frequency, intensity and duration of the attacks, as well as associated symptoms. The results were compared with the use of chi-square test being the one-sided $\mathrm{p}$ value $<$ or $=0.05$, considered significant.

The second step was the study of two groups of 13 patients, randomicaly selected among the first 67 , that were instructed to take sumatriptan $100 \mathrm{mg}$ plus placebo or naproxen sodium $550 \mathrm{mg}$ in a double-blind manner, to treat 3 consecutive attacks occurring in the next 4 weeks. The results were compared with the use of the Fisher's exact test being the one-sided $\mathrm{p}$ value $<$ or $=0.05$, considered significant.

\section{RESULTS}

Two hundred thirty four moderate and 34 severe migraine attacks were treated with the combination during the first step of the study. None of the treated attacks were followed by vomiting that could have impaired the absorption and efficacy of the studied medications. Thirty eight attacks or $14.2 \%$ of the treated attacks, presented recurrence after 2 and within 24 hours. Among the recurring attacks, $7(18 \%)$ were severe, 28 (74\%) moderate and 3(8\%) mild. Prior to the use of the combination, the patients presented recurrence in about 5 out of 8 treated attacks, or at least $62.5 \%$. During the second step of the study, the two groups of 13 patients treated a total of 39 attacks each. In the group that used sumatriptan and placebo, 28 moderate and 11 severe attacks were treated and in the other group, 32 moderate and 7 severe attacks were treated. The patients that took placebo and sumatriptan presented recurrence in 23 attacks (or 59\% recurrence rate). The patients that used the combination sumatriptan and naproxen sodium presented recurrence in 10 attacks (or 25,5\% recurrence rate). Again there were no vomiting after treating the patients.

\section{DISCUSSION}

The recurrence is a major problem with the use of all triptans, some more than others ${ }^{7,8}$, even though it may happen with drugs taken for acute migraine that are not selective agonists of serotonin receptors. According to Ferrari and Visser at least $75 \%$ of patients experienced recurrence in at least some attacks after the use of sumatriptan ${ }^{13}$. Recurrence is defined as the returning of the headache after 2 and before 24 hours, when the severity of the pain firstly decreased from severe or moderate to mild or none. The time to recurrence of the headache after sumatriptan, is around 6-7 hours with the nasal spray, 10 hours with the subcutaneous formulation and 17 hours with the oral presentation ${ }^{2,14-}$ ${ }^{16}$ and a second recurrence may occur in one-third of the patients. In a significant proportion of those patients (up to 70\%), the recurrence may happen even several times in the same attack(multiple recurrence $)^{13,14}$. The underlying mechanisms are still uncertain, but may be related to short plasma half-life and reversible receptor binding of the drug ${ }^{17}$. Usually, most of the patients take a repeated 
dose of sumatriptan to treat the recurrent headache, which is successful in up to $85 \%$ of patients $(2,13)$, although it may recur again ${ }^{2,14}$.

With regard to the use of other triptans, zolmitriptan revealed recurrence with the dose of 5 $\mathrm{mg}$ in $32 \%$ of the attacks and a second dose produced a headache response rate of $90 \%$ at 2 hours postdose $^{18}$. The use of a combination of sumatriptan and a NSAID to decrease recurrence rate has been suggested ${ }^{11,19}$ and studies recommending polytherapy for the acute treatment of migraine have been emphasizing the rational for this option ${ }^{20}$. In this particular group of patients, the combination of the serotonergic agonist sumatriptan and the prostaglandin synthesis inhibitor naproxen sodium, decreased the recurrence rate which was confirmed in the following step of the study, that had a double-blind and therefore controlled methodology. Naproxen sodium inhibits not only the prostaglandin synthesis but the platelet aggregation and the serotonin release from platelets representing a potent anti-inflammatory and analgesic agent which is rapidly absorbed ${ }^{21}$. It has been demonstrated to be effective in prophylactic and acute migraine treatments ${ }^{9,10,22}$.

If we recall that the reported recurrence rate with regard to the use of sumatriptan, vary from 25 to $78 \%$ of the patients, at least occasionally $y^{2,7,8,15}$, the use of this specific combination or the association of a triptan and a NSAID to reduce this limiting prescribing factor, may be recommended as an usual approach specially in those patients with a good response to sumatriptan and a high recurrence rate.

\section{REFERENCES}

1. Oral Sumatriptan Dose-Defining Study Group. Sumatriptan: an oral dose-defining study. Eur Neurol 1991;31:300-305

2. Ferrari MD, James MH, Bates D, et al. Oral sumatriptan: effect of a second dose, and incidence and treatment of headache recurrences. Cephalalgia 1994;14:330-338

3. Doenicke A, Brand J, Perrin VL. Possible benefit of GR43175, a novel 5-HT1-like receptor agonist, for the acute treatment of severe migraine. Lancet 1988;1:1309-1311

4. Peroutka SJ. Sumatriptan in acute migraine: pharmacology and review of world experience. Headache 1990;30(Suppl 2):554-560

5. Visser WH, Klein KB, Cox RC, Jones D, Ferrari MD. 311C90, a new central and peripherally acting 5-HT1D receptor agonist in the acute treatment of migraine: a double-blind, placebo-controlled, dose-range finding study. Neurology 1996;46:522-526.

6. Cutler NR, Claghorn J, Sramek JJ, et al. Pilot study of MK-462 in migraine. Cephalalgia 1996;16:113-116.

7. Dalhof CG. How does sumatriptan perform in clinical practice ? Cephalalgia 1995;15(Suppl15):21-28

8. Tfelt-Hansen P. Sumatriptan for the treatment of migraine attacks: a review of controlled clinical trials. Cephalalgia 1993; 13:238-244.

9. Nestvold K, Kloster R, Partinem M, Sulkava R. Treatment of acute migraine attack: naproxen and placebo compared. Cephalalgia 1985;5:115-119.

10. Johnson ES, Ratcliffe DM, Wilkinson M. Naproxen sodium in the treatment of migraine. Cephalalgia 1985;5:5-10.

11. Krymchantowski AV, Adriano M, Fernandes D. Tolfenamic acid decreases migraine recurrence when used with sumatriptan. Cephalalgia 1999;19:186-187.

12. Headache Classification Committee of the International Headache Society. Classification and diagnostic criteria for headache disorders, cranial neuralgias and facial pain. Cephalalgia 1988;8(Suppl7):1-8.

13. Ferrari MD, Visser WH. Sumatriptan in clinical practice: a 2-year review of its effects and limitations. In: Olesen J, TfeltHansen P (eds). Headache treatment: trial methodology and new drugs. Philadelphia: Lippincott-Raven 1997;30:181-188.

14. Visser WH, de Vriend RH, Jaspers MW, Ferrari MD. Sumatritpan in clinical practice: a 2-year review of 453 migraine patients. Neurology 1996;47:46-51.

15. Dechant KL, Clissold SP. Sumatriptan: A review of its pharmacokinetic properties, and therapeutic efficacy in the acute treatment of migraine and cluster headache. Drugs 1992;43:776

16. Plosker GL, Mc Tavish D. Sumatriptan: A reappraisal of its pharmacology and therapeutic efficacy in the acute treatment of migraine and cluster headache. Drugs 1994;47:622

17. Goadsby P, Silberstein SD. In: Blue Books of Practical Neurology Vol. 17 Headache. Boston: Butterworth-Heinemann 1997;8:123

18. The International 311C90 Long-term Study Group. The long-term tolerability and efficacy of oral zolmitriptan (Zomig 311C90) in the acute treatment of migraine: an international study. Headache 1998;38:173-183.

19. Krymchantowski AV, Moreira PF, Adriano M. Naproxen sodium decreases migraine recurrence when used with sumatriptan (Abstr). Cephalalgia 1999;4:357.

20. Peroutka SJ. Beyond monotherapy: rational polytherapy in migraine. Headache 1998;38:18-22.

21. Pradalier A, Rancurel G, Dordain G, Verdure L, Rascol A, Dry J. Acute migraine attack therapy: comparison of naproxen sodium and an ergotamine tartrate compound. Cephalalgia 1985;5:107-113

22. Lindegaard KF, Ovrelid L, Sjaastad O Naproxen in the prevention of migraine attacks: a double-blind placebo-controlled cross-over study. Headache 1980;20:96-98 . 